Dragana Marković

NacionIna biblioteka Crne Gore

"Djurdje Crnojević" Cetinje
004.738.5:316.472.4]:027

https://doi.org/10.18485/melissa.2017.16.1.ch13

\title{
KORIŠĆENJE DRUŠTVENIH MREŽA U BIBLIOTEKAMA CRNE GORE
}

\begin{abstract}
Sažetak
Masovno širenje društvenih medija postalo je izuzetno popularno među korisnicima informacija. Društveni mediji su uticali na način na koji korisnici pristupaju i koriste informacije, u svim aspektima njihovih života, čime postaju globalni fenomen za stalne rasprave. Različite web stranice društvenih medija stvorile su eksploziju informacija, a pristup informacijama postao je liberalniji nego ikad prije. Kako bi se spriječila etička kriza, hitna je potreba, da biblioteke preusmjere svoje ciljeve, strategije i politike kako bi identifikovale ove etičke rupe i zapečatile ih u korist svojih korisnika, prije nego što bude prekasno.
\end{abstract}

Ključne riječi: društveni mediji, komunikacija, informacije, korisnici, biblioteka

Sve više i više biblioteke koriste društvene medije za povezivanje $s$ korisnicima. Od Facebooka i Twittera do Pinteresta i YouTubea, biblioteke otvaraju širok raspon računa kako bi se angažovali korisnici i tržišni lokalni resursi. Dok bibliotekari moraju naučiti tehnologiju i format iza svakog alata za društvene medije, jedan od najvećih izazova u upravljanju društvenim medijima generiše SADRŽAJ.

Kako bi profili bili aktivni, biblioteke moraju redovno objavljivati i ažurirati svoje stranice. Iste moraju biti sadržajne, interesantne i zanimljive kako bi privukle veliki broj svojih korisnika.

U nastojanju da riješim ovo pitanje, sprovela sam ova pitanja u istraživanje, kako biblioteke trenutano koriste i primjenjuju društvene medije u bibliotekama Crne Gore. Cilj mi je, dati mjerilo iz koje biblioteke 
mogu mjeriti vlastitu društvenu medijsku aktivnost i daju najbolje prakse i preporuke, koje bi nadahnule druge biblioteke da isprobaju nove pristupe.

Ovo istraživanje koristi fenomenološki pristup i institucionalnu teoriju za istraživanje društvenih medija u različitim tipovima biblioteka u Crnoj Gori. U istraživanju “Društveni mediji i biblioteke”, su učestvovali 23 bibliotekara/ke. Rezultati dobijeni istraživanjem, prikazani su grafikonima.

Cilj istraživanja je utvrditi kako bibliotekari trenutno koriste društvene medije u svojim ulogama.

\section{Tip biblioteke?}

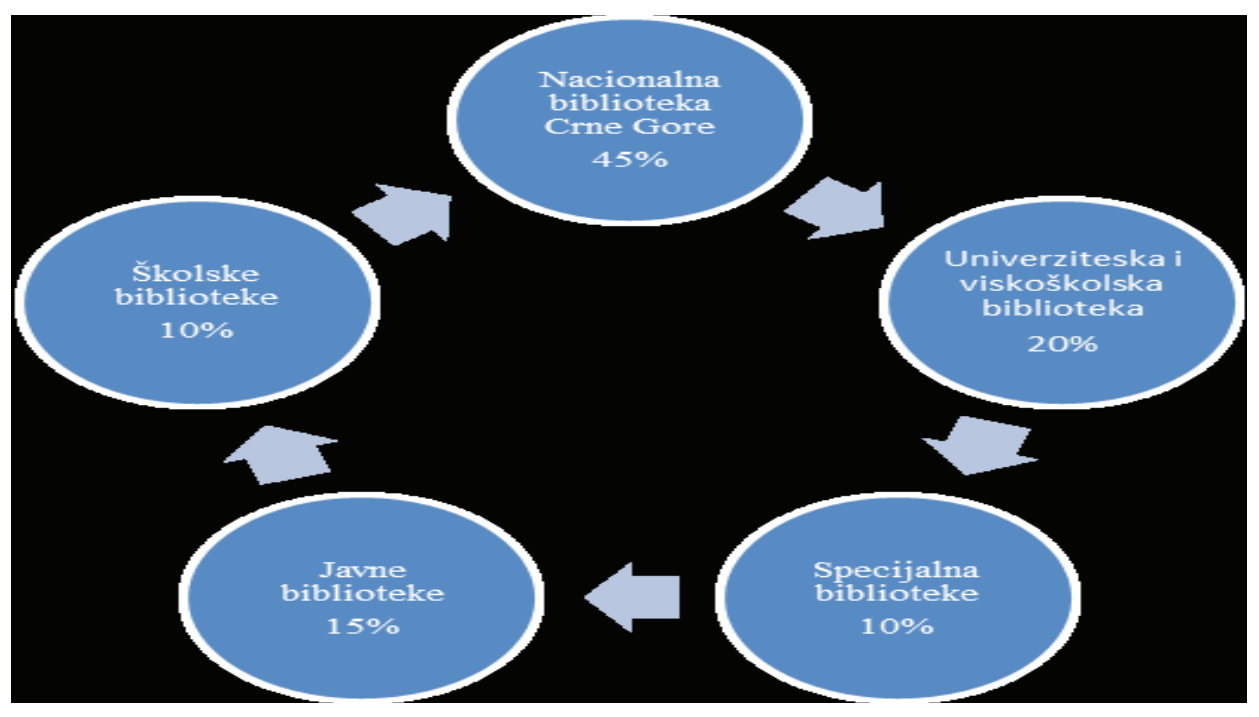




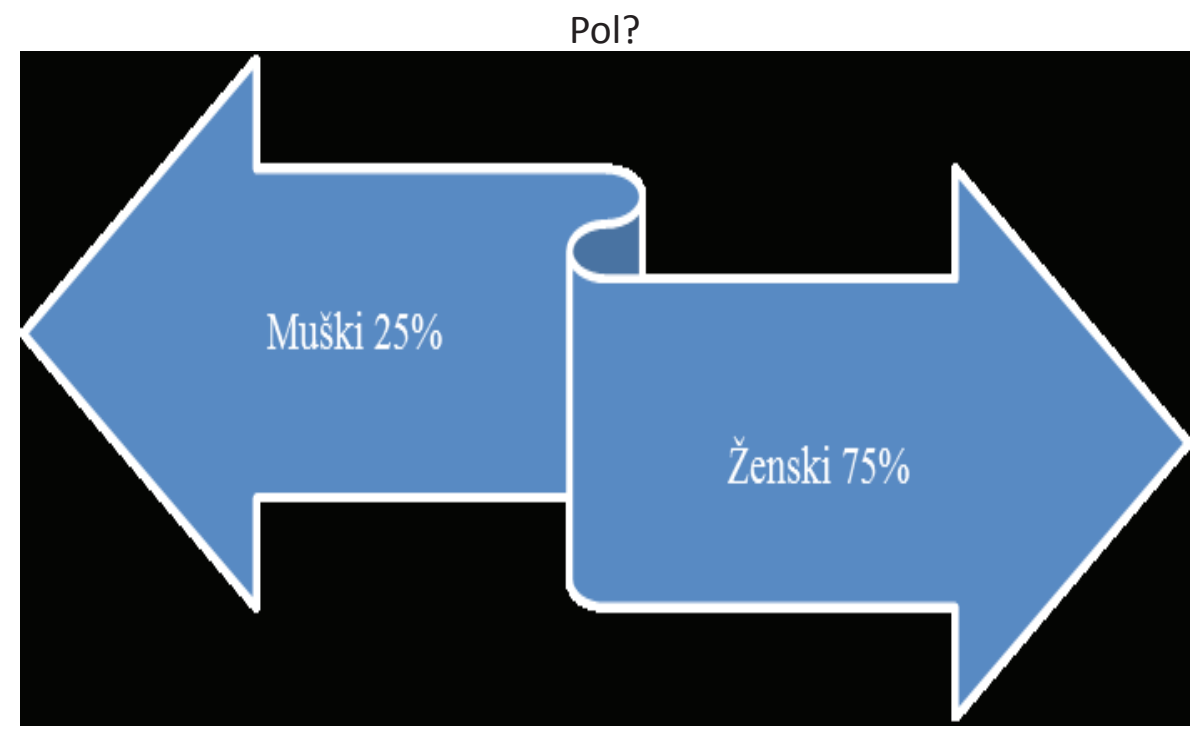

Kojoj od navedenih starosnih grupa pripadate?

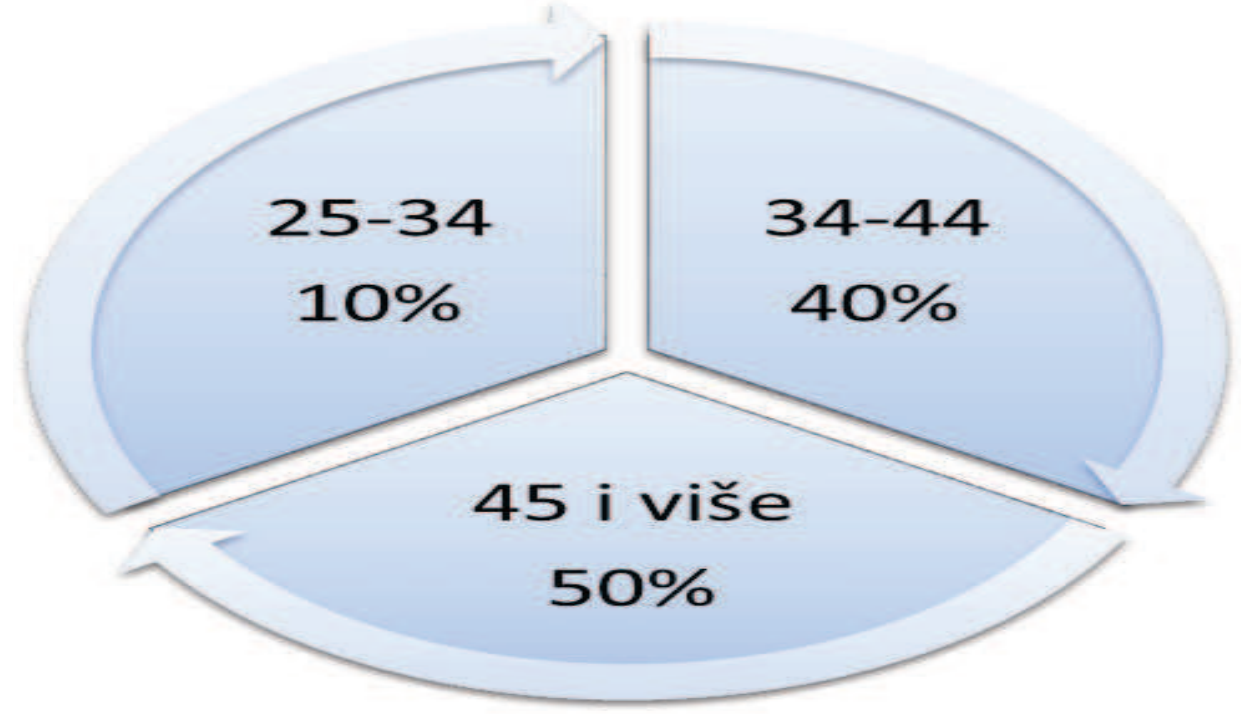


Vaš status?

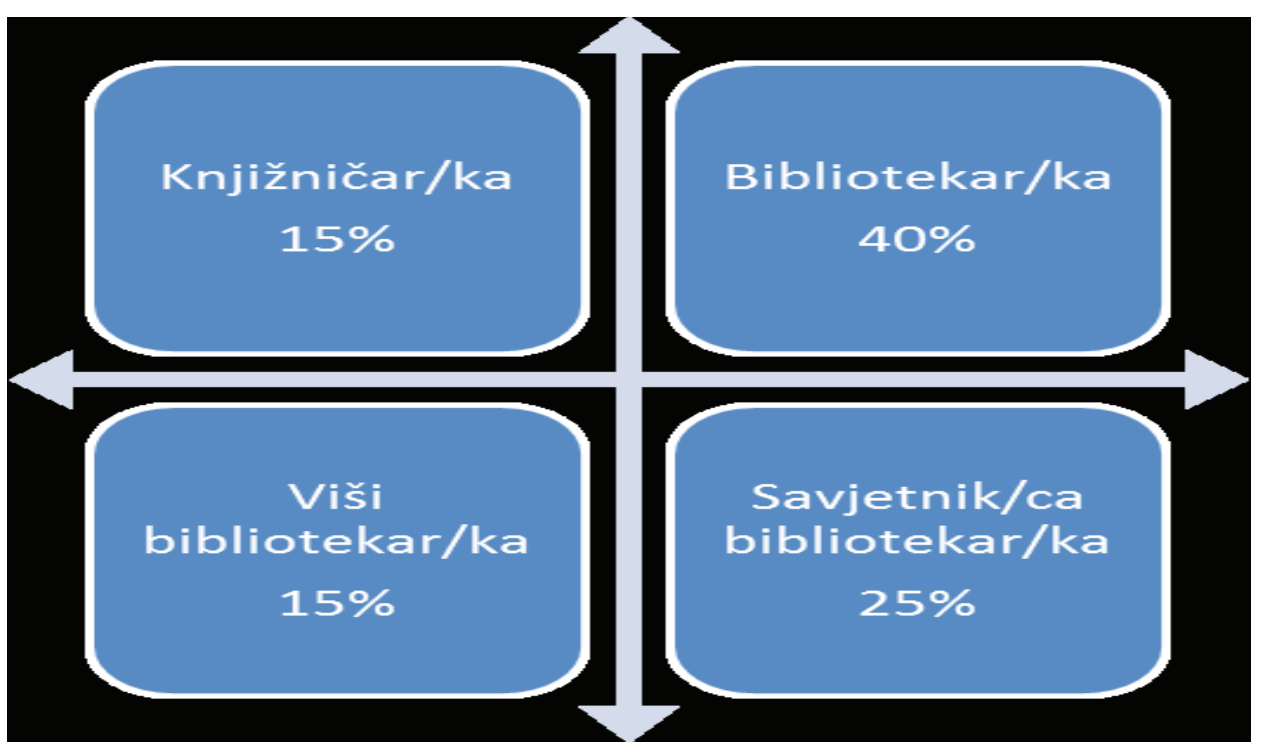

Koristite li neke od navedenih društvenih mreža?

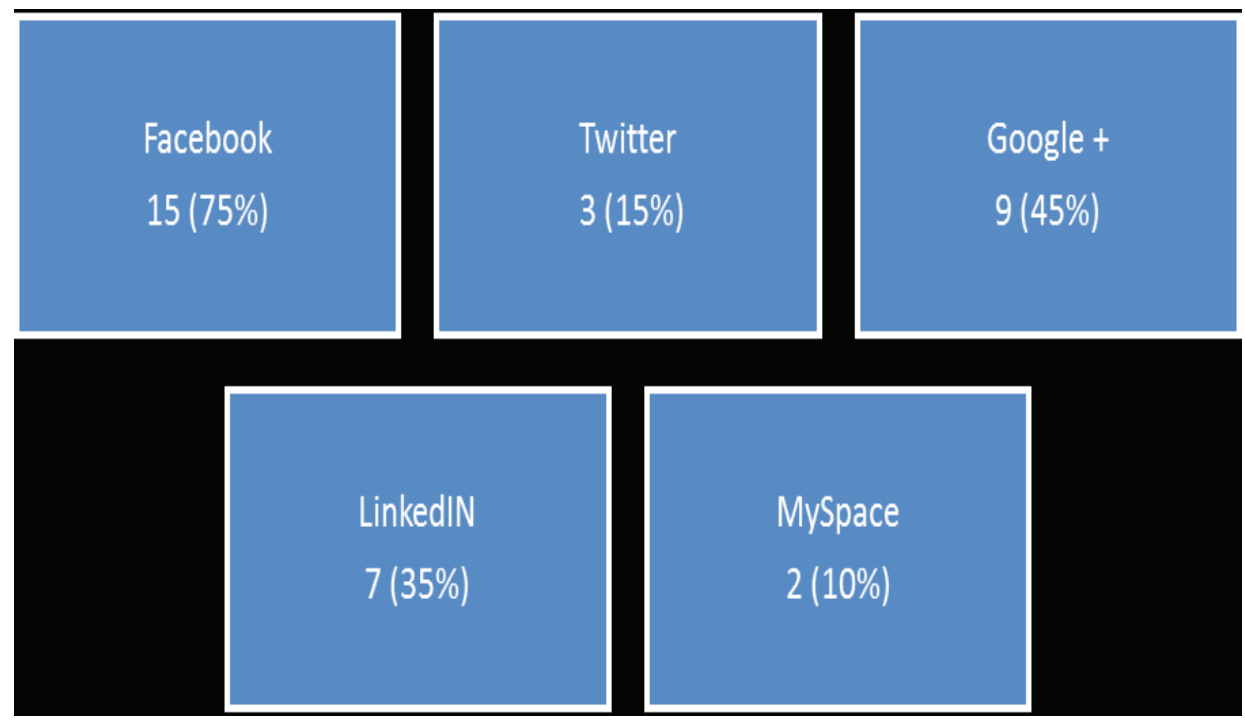


U prosjeku, koliko vremena provodite na društvenim mrežama?

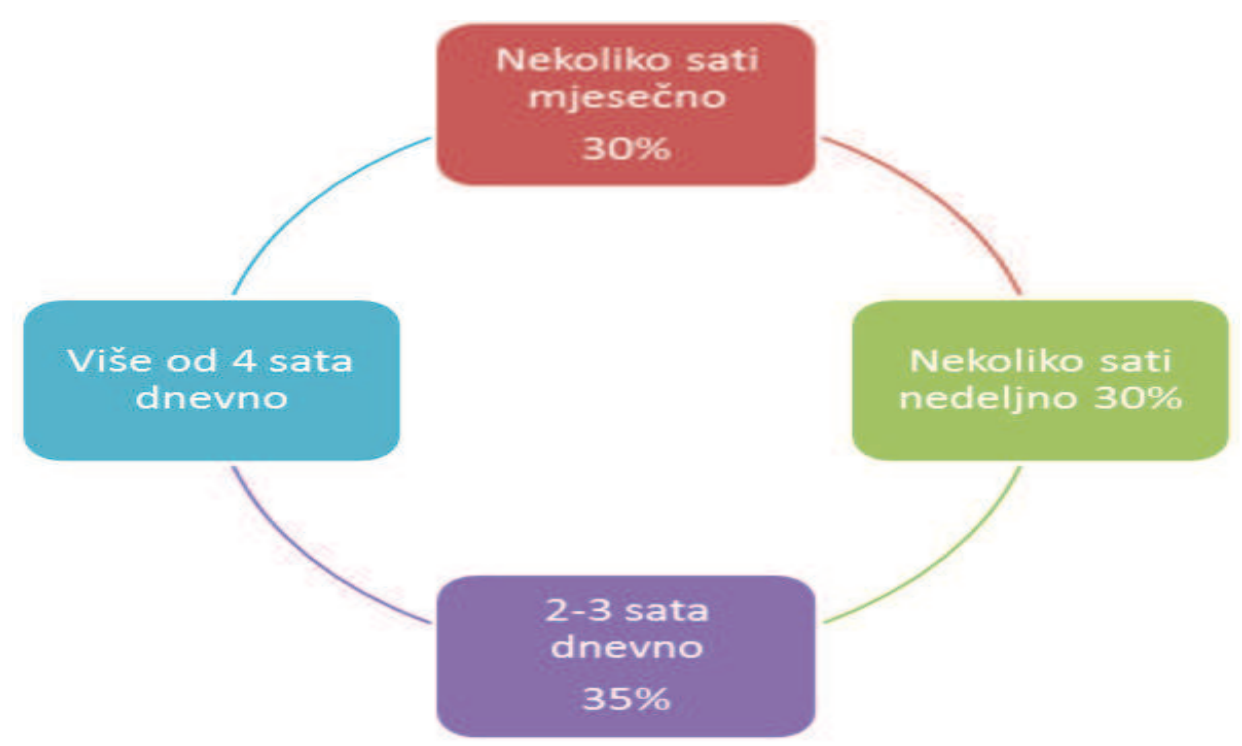

Pristupate li društvenim mrežama putem mobilnog telefona?

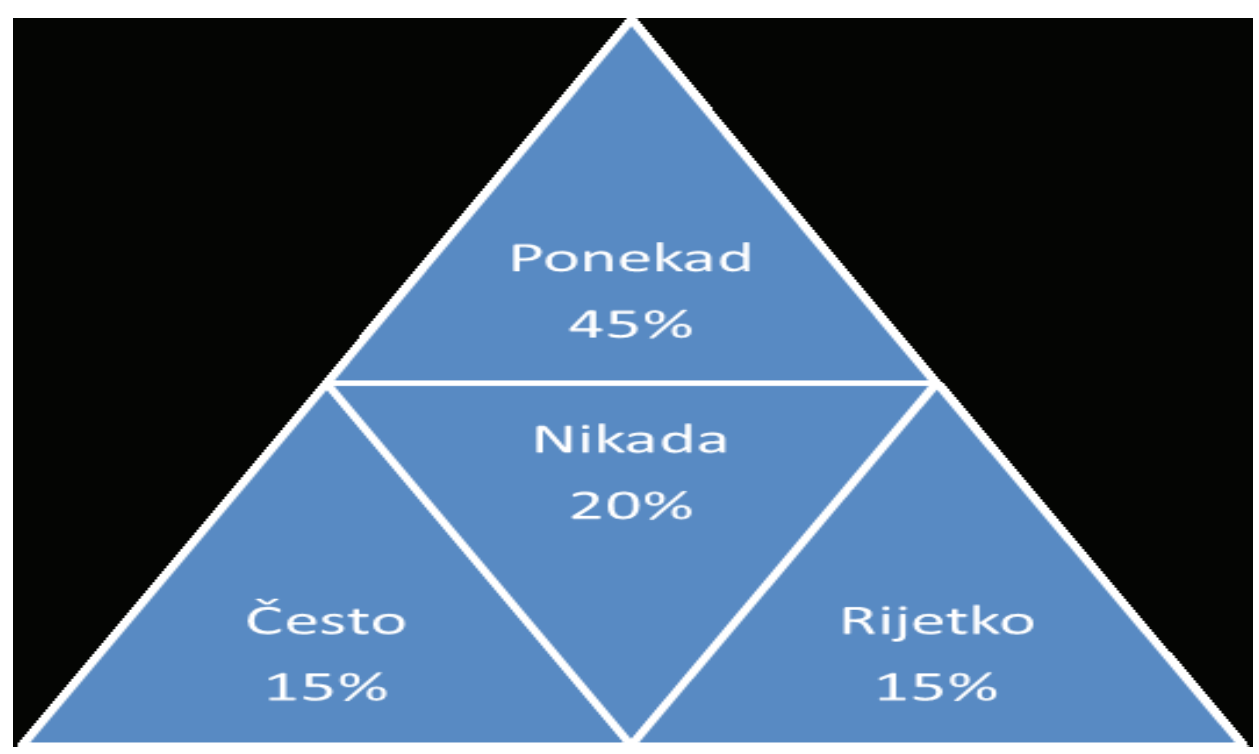


Učlanjujete li se u bibliotečke grupe na društvenim mrežama?

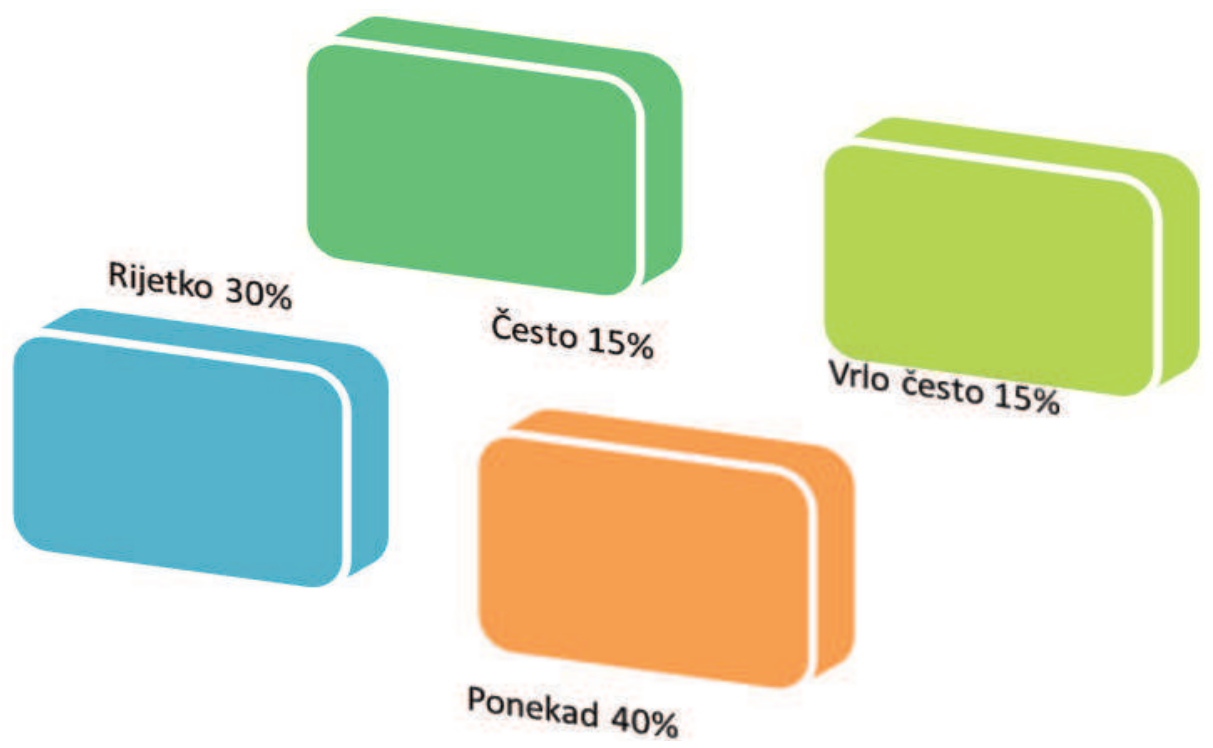

Društvenu mrežu najčešće koristite za:

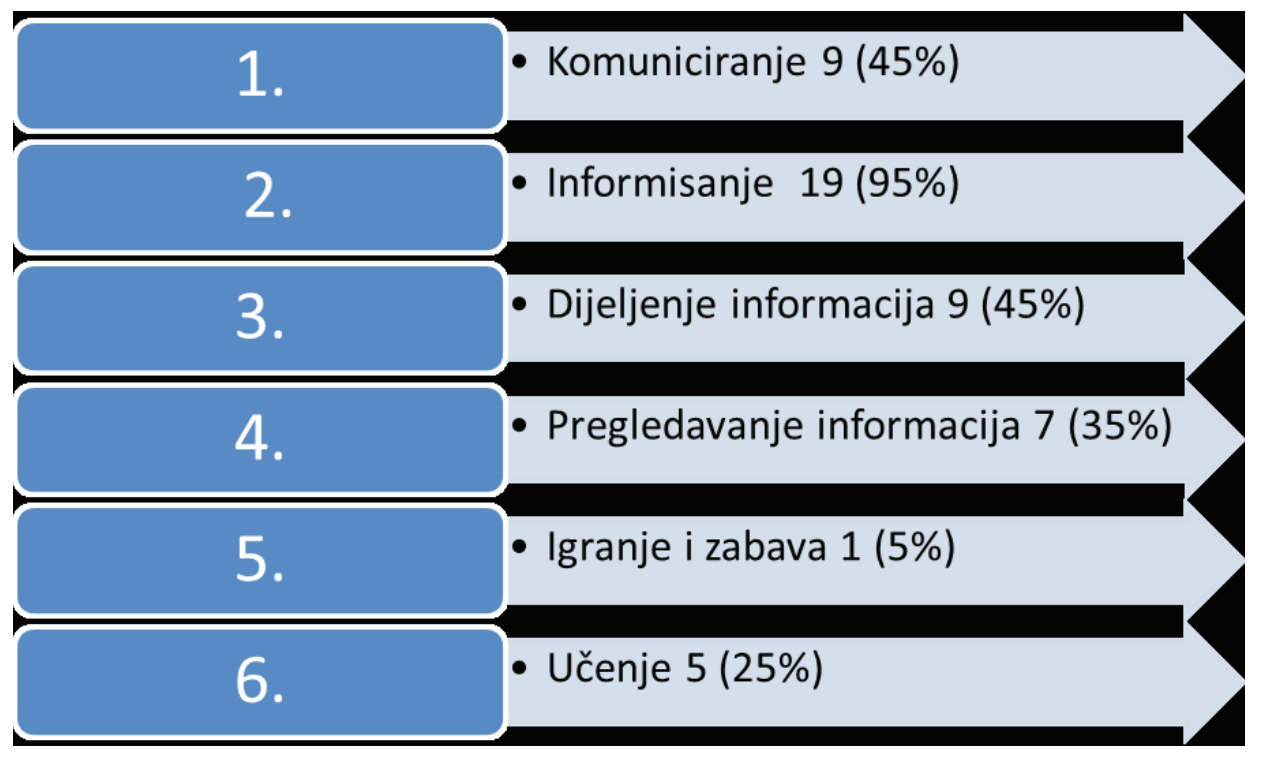


Sadržaje na društvenoj mreži objavljujete:

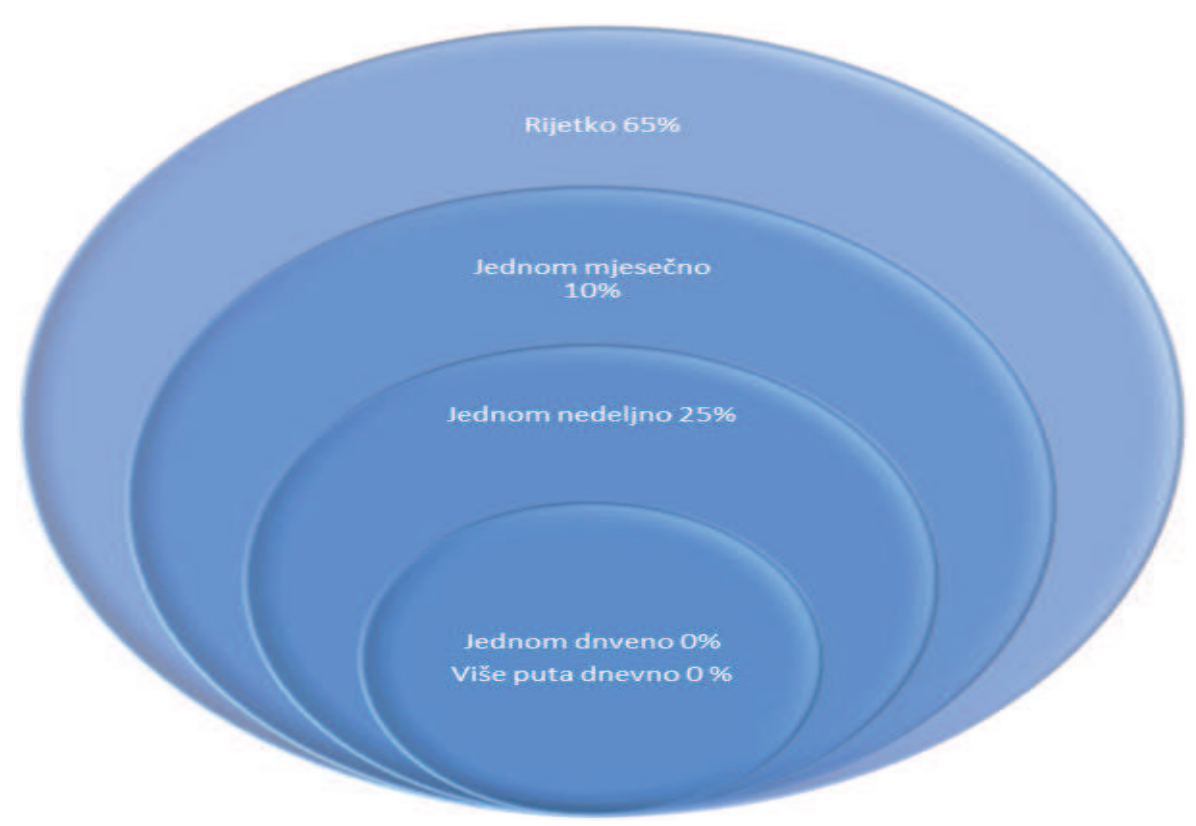

Objave prijatelja i poruke na društvenim mrežama provjeravate

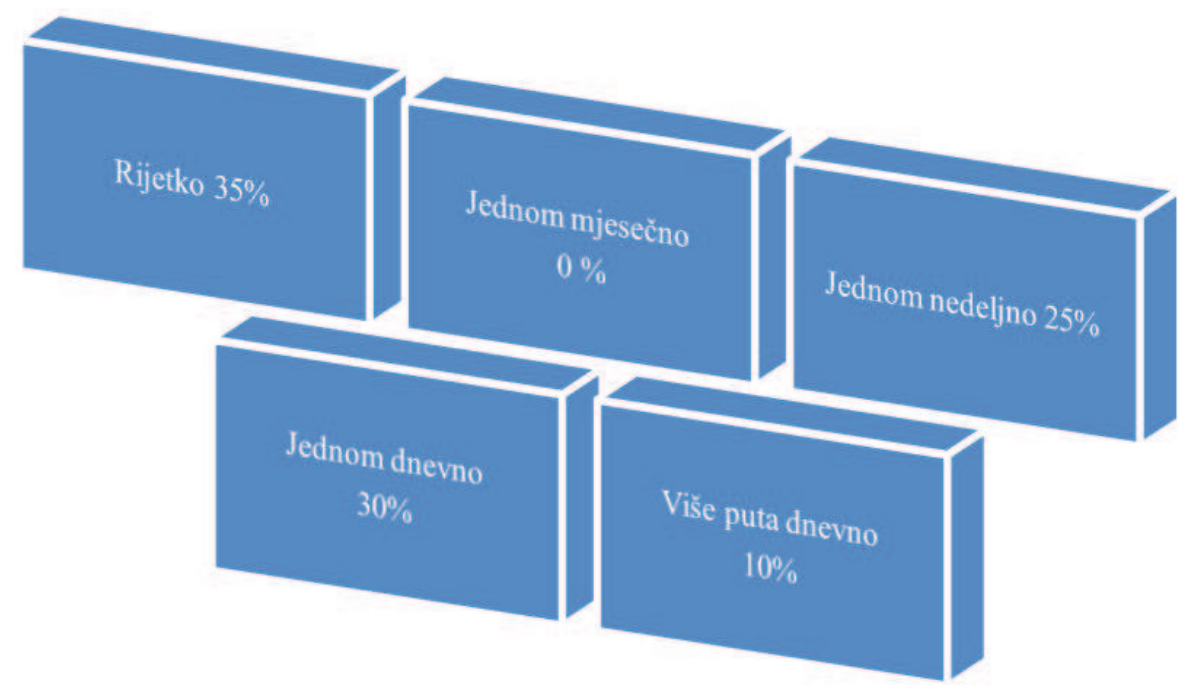


Jeste li zabrinuti zbog dostupnosti vaših ličnih podataka na društvenim mrežama?

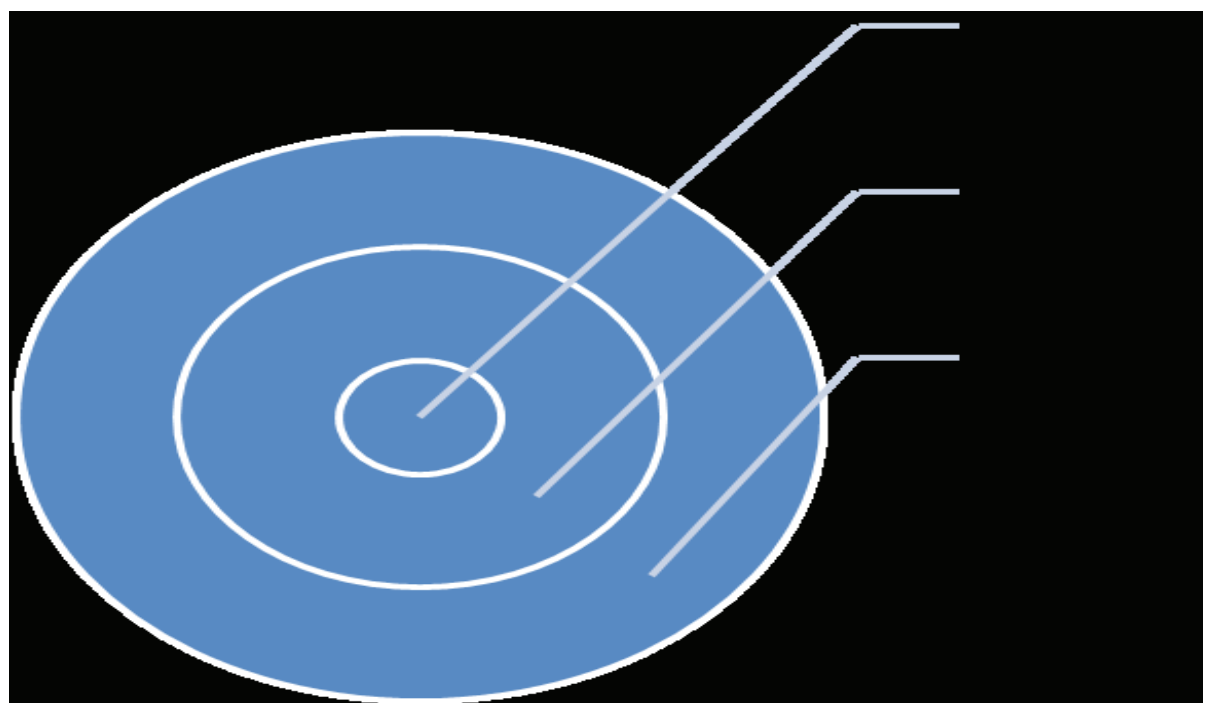

Pristupate li društvenim mrežama tokom radnog vremena?

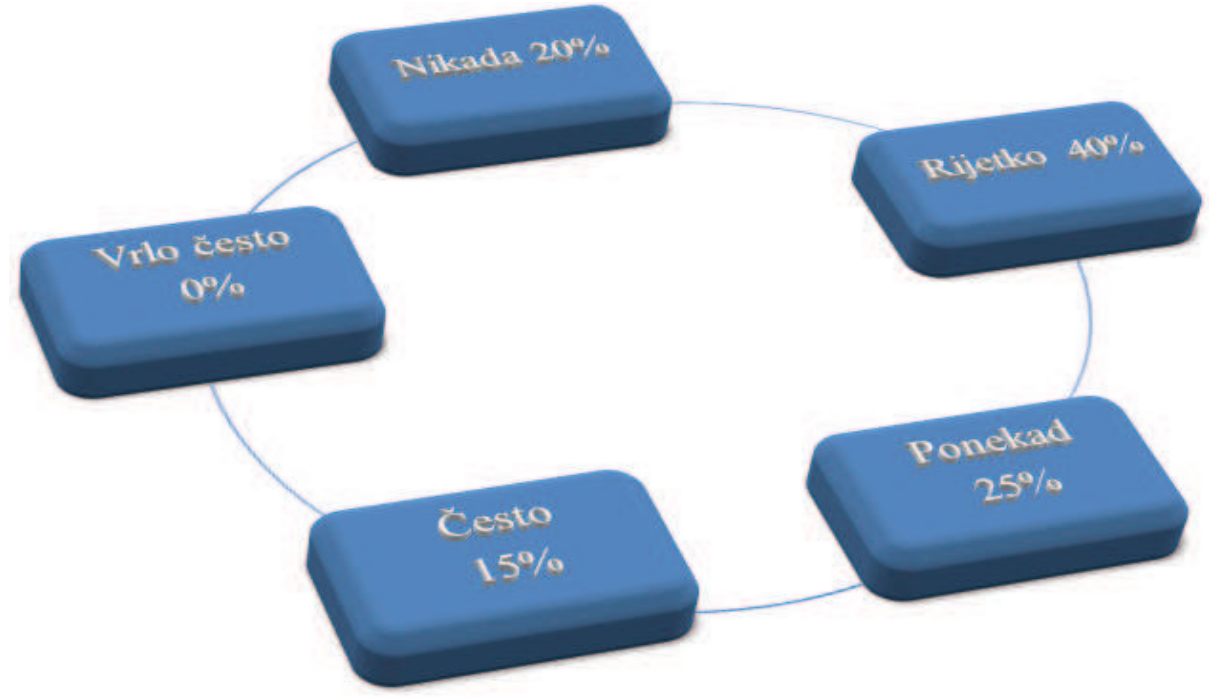


Zanemarujete li svoje obaveze zbog upotrabe društvenih mreža?
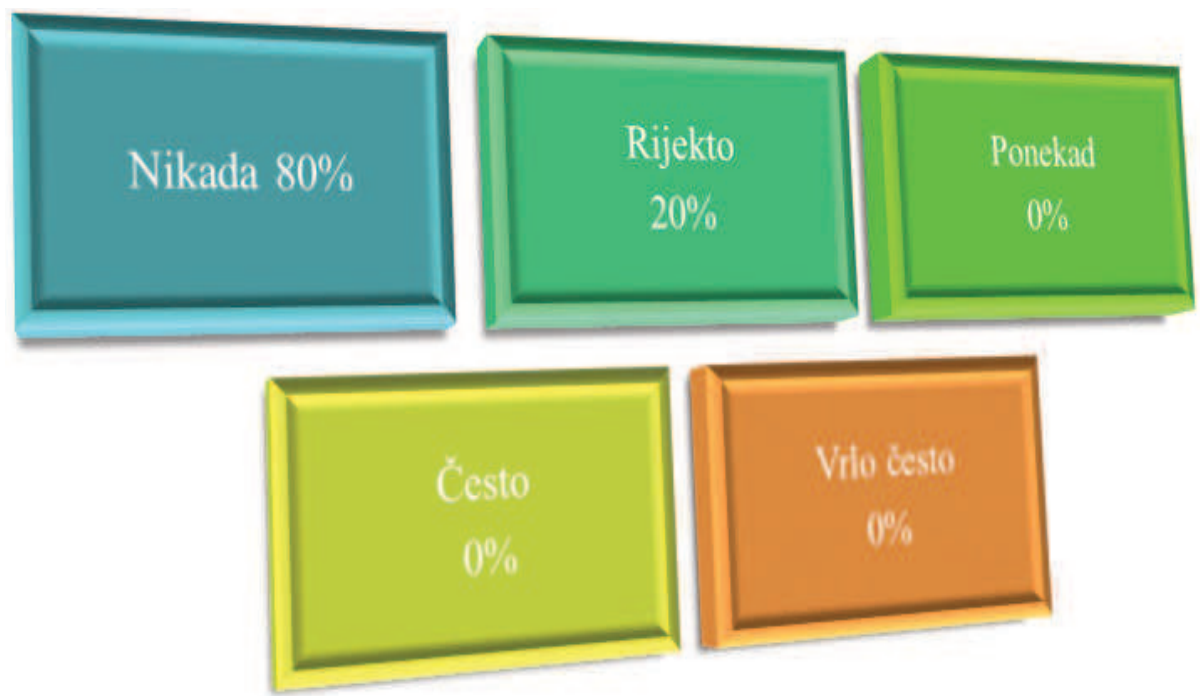

Koristi li vaša biblioteka društve mreže i koje?

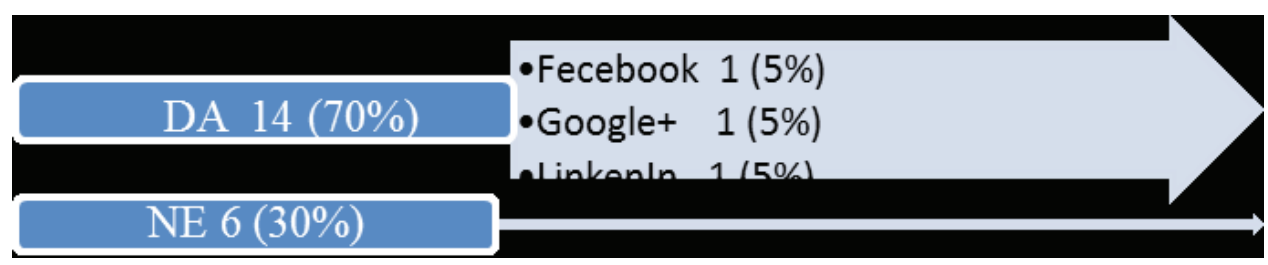


Ako koristi, koliko često pratite objave?

\section{Nikada $20 \%$}

Rijetko $25 \%$

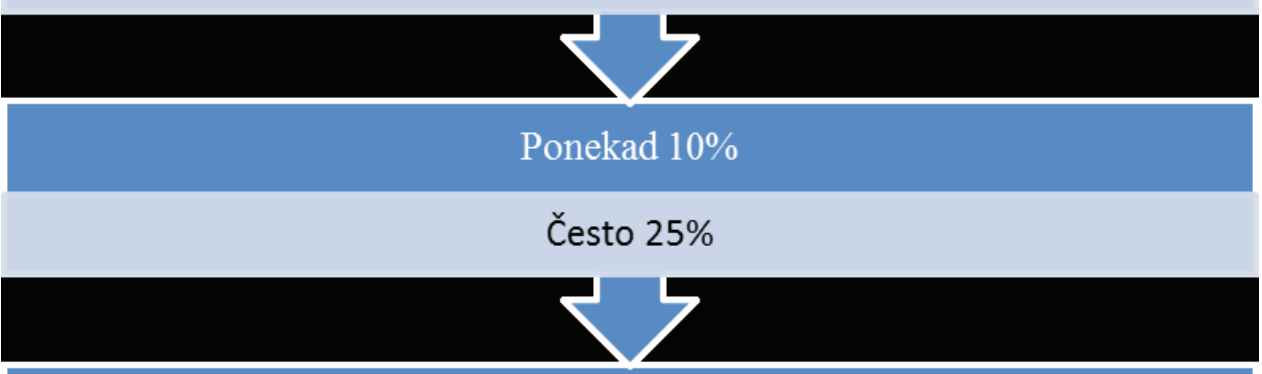

\section{Vrlo često $20 \%$}

Pratite li druge biblioteke na društvenim mrežama?

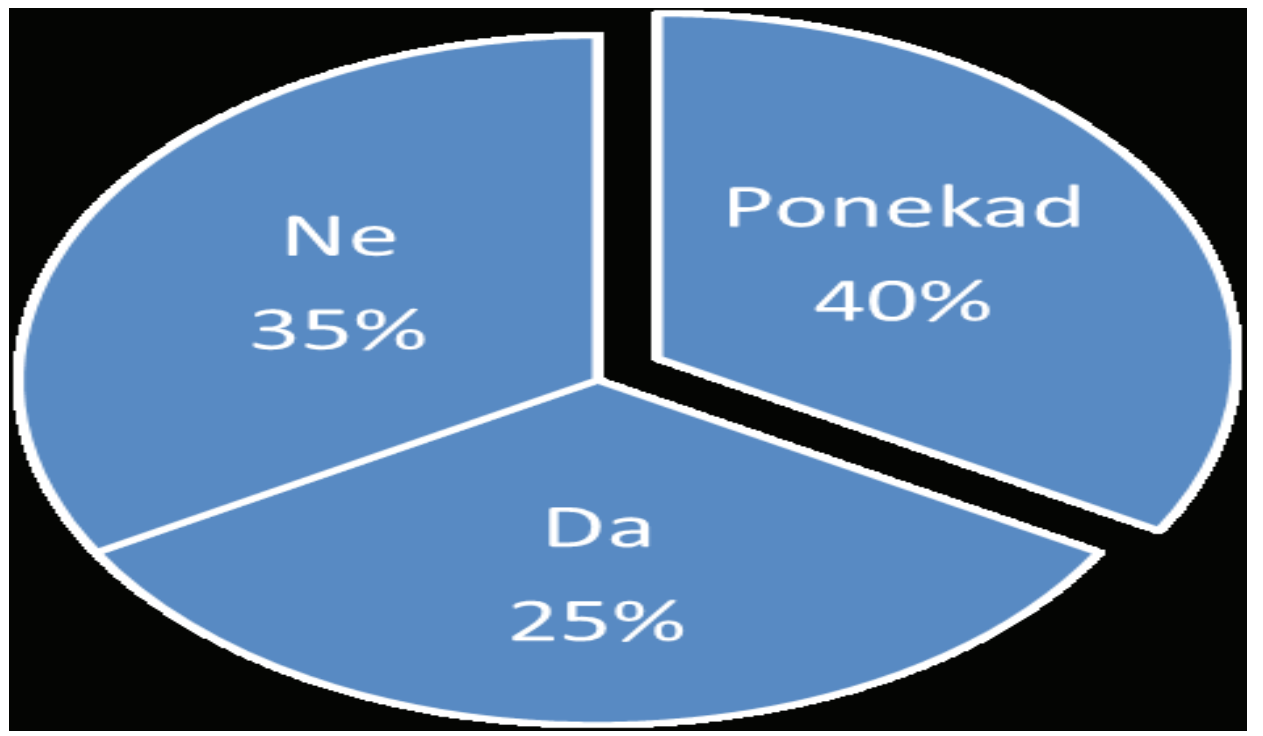


Da li su većina vaših prijatelja na društvenim mrežama bibliotekari?

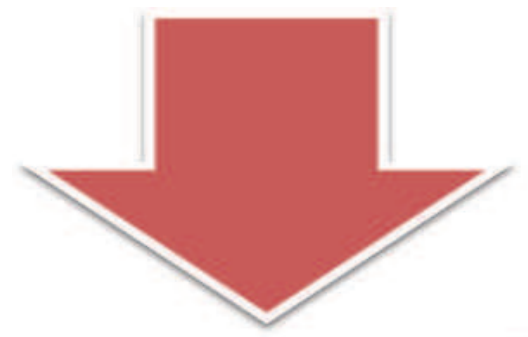

$\mathrm{Ne}$

$90 \%$

Da

$10 \%$

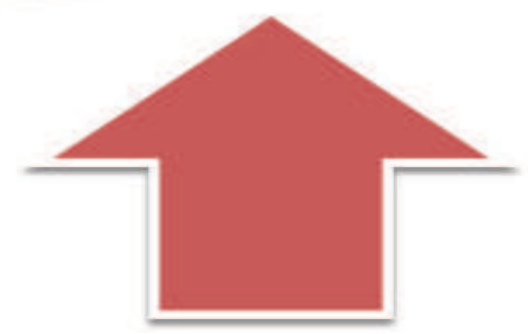

Na društvenim mrežama ste prijavljeni pod svojim:
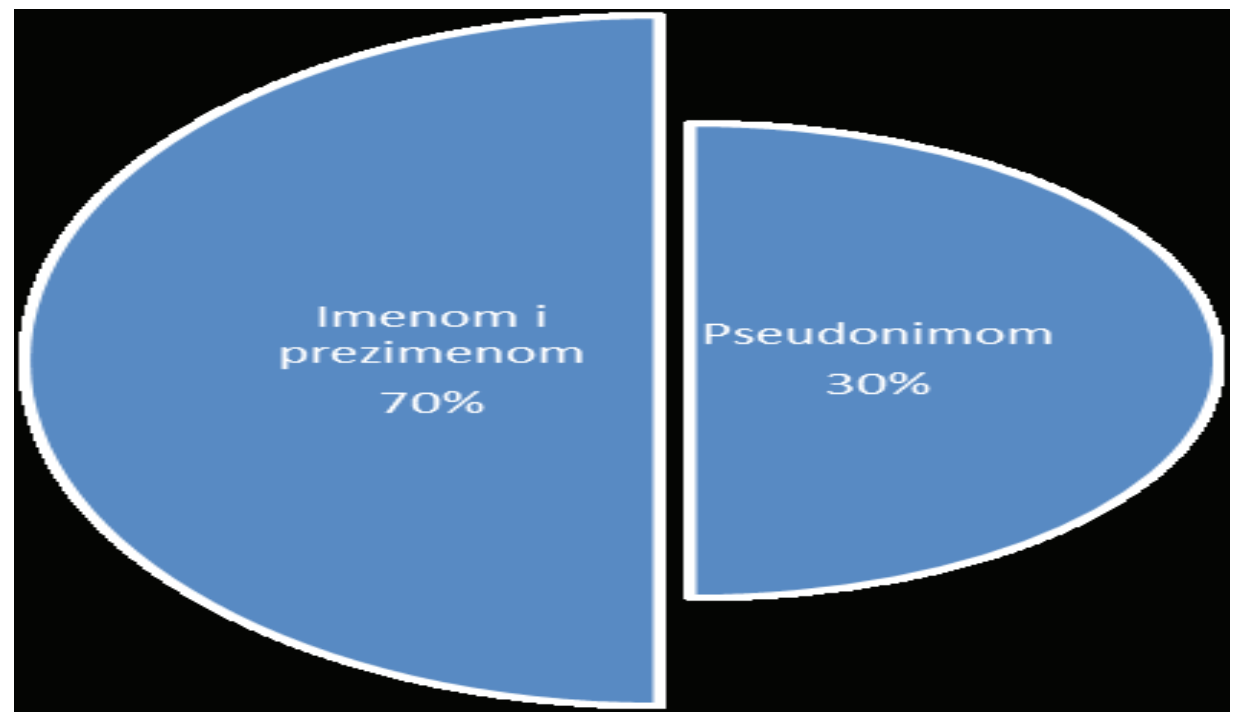
Koji od navedenih sadržaja objavljujete na društvenim mrežama?
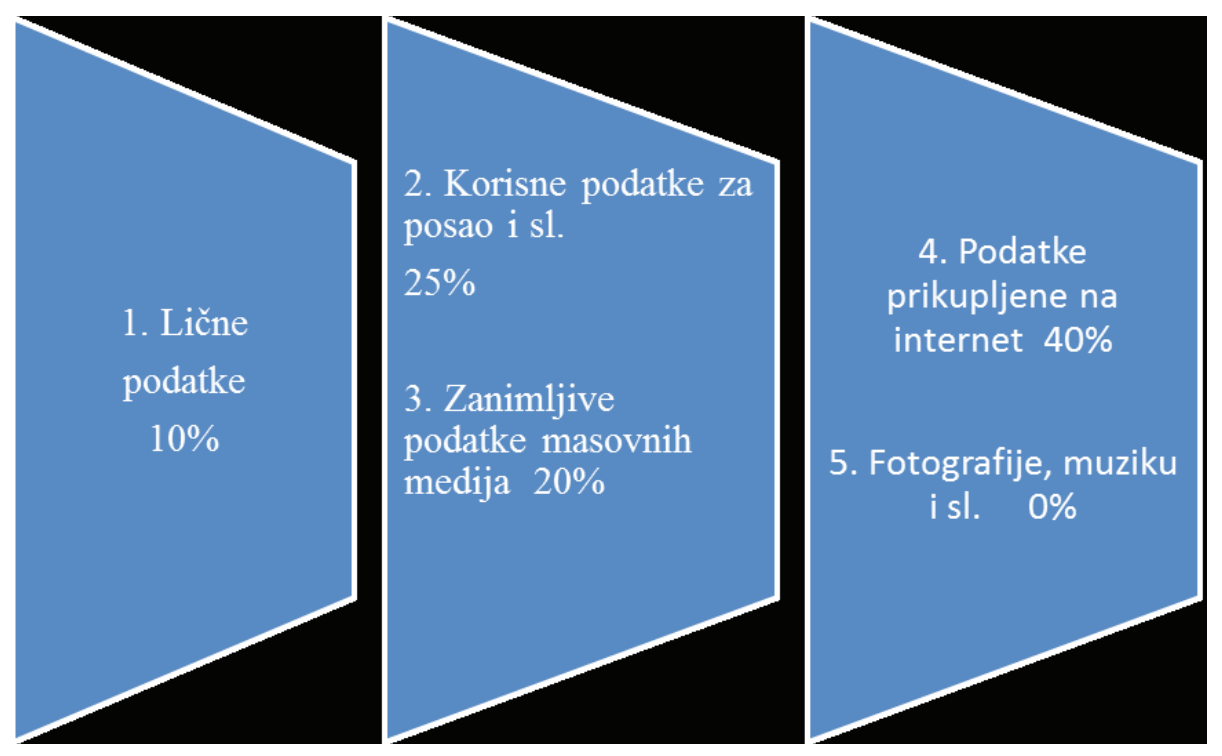

Objavljeni sadržaj na vlastitom profilu društvenih mreža dijelite s:

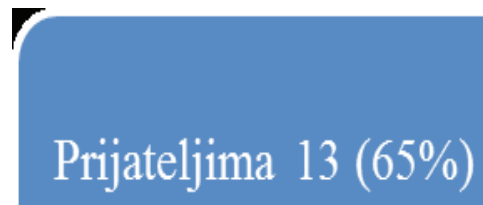

\section{Javno $3(15 \%)$}


Jeste li imali kakvih negativnih iskustava s društvenim mrežama?

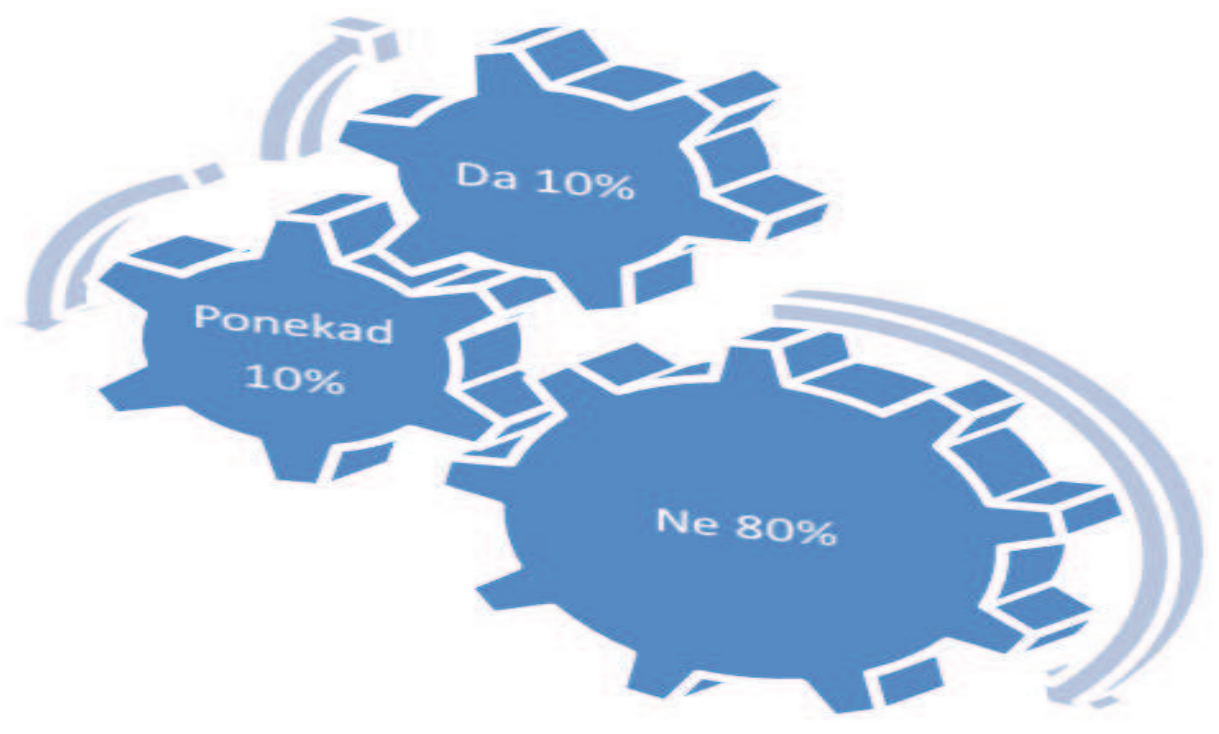

Dragana Marković, bibliotekarka savjetnica

Rezime

Društveni mediji imaju potencijal da olakšaju mnogo bliže odnose između biblioteka i njihovih korisnika. Sadašnja upotreba društvenih medija od strane bibliotečke zajednice uglavnom ostaje ad hoci donekle eksperimentalna, alise ubrzava upotreba ovih alata iverovatno će igrati sve važniju ulogu u pružanju bibliotečkih usluga i dosadašnjoj informisanosti. Upotreba društvenih medija u biblioteci može uticati, da bibliotekari/ke:

- naučit kako efikasno uključiti strategiju društvenih medija u marketing planove, razumijevati mogućnosti različitih kanala i kako se oni mogu prilagoditi individualnim potrebama vaše biblioteke;

- shvatite kako trendovi u bibliotekarstvu utiču na korištenje društvenih medija, kako se korištenje društvenih medija može razlikovati od uloge posla i kako možete prenijeti ovo znanje kako biste povećali efikasnost vaše uloge.

\section{Summary}

Dragana Marković, library consultant

Social media has the potential to ease much closer relations be- 
tween libraries and their users. The current use of social media by the library community largely remains ad hoc and somewhat experimental, but speeds up the use of these tools and will likely play an increasingly important role in the provision of library services and up-to-date information.

The use of social media in the library can influence librarians:

- learn how to effectively integrate a social media strategy into marketing plans, understand the capabilities of different channels, and how they can be tailored to your individual library needs;

- Understand how trends in librarianship affect the use of social media, how the use of social media can be different from the role of the job and how you can transfer this knowledge to increase the effectiveness of your role. 